IJPDLM

49,5

492

Received 30 January 2018

Revised 7 June 2018

19 August 2018

23 October 2018

12 December 2018

Accepted 17 December 2018

\section{Driving impact through base of the pyramid distribution models The role of intermediary organizations}

\author{
Valeria Varga \\ Rotterdam School of Management, \\ Erasmus University Rotterdam, Rotterdam, The Netherlands, and \\ Eugenia Rosca \\ Department of Management, Tilburg University, Tilburg, The Netherlands
}

\begin{abstract}
Purpose - The purpose of this paper is to answer the following research question: how can intermediaries contribute to social impact creation through their interventions at different levels of distribution networks in the base of the pyramid (BoP) markets?

Design/methodology/approach - The paper adopts an embedded case study of an intermediary organization. The analysis focuses on the intervention of the intermediary on the distribution stages of supply chains in four different projects in the food sector in Ethiopia, Benin, Nigeria and Bangladesh.

Findings - The embedded case study reveals essential formal and informal roles undertaken by the intermediary organization to develop decentralized distribution networks based on local micro-entrepreneurs. The study proposes that efforts undertaken by the intermediaries toward knowledge sharing and capacity building among partners can enable the adoption of pro-poor strategies across the supply chain. Moreover, hybrid intermediaries can act as "guardians" of the mutual value creation approach since one of their key roles is to advocate the needs of the BoP.

Research limitations/implications - Important implications for improving nutrition and food security in the BoP markets are developed based on the empirical findings. The findings open avenues for further research into the antecedents of retention rates in distribution networks based on local micro-entrepreneurs. Practical implications - Findings have implications for different types of BoP initiatives by highlighting how intermediary organizations intervene to develop distribution models with a special focus on social impact. Originality/value - This paper fills an important research gap by discussing social impact aspects in BoP supply chains by adopting the perspective of intermediary organizations.
\end{abstract}

Keywords Market development, Social value creation, Social impact, Base of the Pyramid, Intermidiaries Paper type Research paper

\section{Introduction}

The main claim of the base of the pyramid $(\mathrm{BoP})$ literature is that businesses in these markets are capable of mutual value creation - simultaneously creating profit and alleviating poverty (London et al., 2010; Prahalad and Hammond, 2002). However, many practitioners and academics question whether BoP ventures can fulfill such promises (Smith et al., 2016). Literature points to numerous challenges which can hinder these enterprises from achieving mutual value creation (London et al., 2010). Some of the main external challenges are due to the institutional voids in BoP markets (Stephan et al., 2015). The internal challenges originate from the lack of relevant

(C) Valeria Varga and Eugenia Rosca. Published by Emerald Publishing Limited. This article is published under the Creative Commons Attribution (CC BY 4.0) licence. Anyone may reproduce, distribute, translate and create derivative works of this article (for both commercial and non-commercial purposes), subject to full attribution to the original publication and authors. The full terms of this licence may be seen at http://creativecommons.org/licences/by/4.0/legalcode

Many agree that partnerships are the way forward on frontier markets - without a collaborative effort, one does not get far. The same applies to this research. The authors would like to thank everyone who contributed to this paper, especially: Dr Addisu Lashitew and Prof Dr Lucas Meijs for their guidance; Arpan Rijal for his insightful comments, the BoP Innovation Center and all the interviewees for their time and trust; and all the guest editors and reviewers for their valuable feedback.
International Journal of Physical Distribution \& Logistics Management Vol. 49 No. 5 ,
pp. $492-513$ Emerald Publishing Limite 0960-0035 DOI 10.1108/IJPDLM-01-2018-0040 
knowledge and skills of entrepreneurs and small, medium and large firms (Smith et al., 2016). Within BoP markets, companies in particular face significant challenges related to supply chain design and operation (Karamchandani et al., 2011). First, firms face weak infrastructure and almost non-existent formal institutions which traditionally support product, labor and capital markets (Parmigiani and Rivera-Santos, 2015). Second, companies need to balance standardization approaches (to enable economies of scale) with localization approaches (to ensure adaptations to local culture and social norms) (Fawcett and Waller, 2015). Specifically, the lack of adequate infrastructure in rural communities or urban slums, where most $\mathrm{BoP}$ population live, makes it challenging for large firms to adopt the traditional large-scale distribution models focused on economies of scale and stocked shelves (Fawcett and Waller, 2015).

In order to overcome institutional voids, firms aiming to expand to $\mathrm{BoP}$ markets need to develop new, unconventional alliances and partnerships with local formal and informal organizations. In these settings, unconventional partners can take over vital roles in the value chain (Gold et al., 2013). In this sense, a new type of critical partner has emerged from practice and gained attention in the academic literature - "intermediary organizations." Intermediary organizations are actors from public, not-for-profit or private sector which perform key roles in the network by connecting different stakeholders and intervene at both micro and macro levels in BoP initiatives (Kistruck et al., 2013).

Although recognition of their significant efforts for the success of $\mathrm{BoP}$ ventures is growing, their role in business and supply chain development is not yet well understood. Literature calls for more research on the strengths and limitations of intermediary activity (Clarke and Ramirez, 2014; Kistruck et al., 2013). Intermediary organizations support BoP supply chains at different levels; yet, the question arises: how do these interventions contribute to social value creation for local $\mathrm{BoP}$ communities? Answering this question is important both for capital providers (e.g. donors and impact investors) who demand upward accountability and for the intermediary organizations since it can be a matter of accountability toward their own mission.

This leads to the following research question:

RQ1. How can intermediaries contribute to social impact creation through their interventions at different levels of distribution networks in BoP markets?

The levels of distribution networks denote different stages and activities performed by various actors in the process of bringing products to final consumers. This study aims to understand interventions of intermediaries at different stages of the distribution networks and explore specific mechanisms which can lead to (or hinder) social impact creation. The research question is studied in an embedded case study of a Dutch intermediary organization, the BoP Innovation Center (BoPInc). The analysis is focused on the intervention of the intermediary in four different projects in the BoP markets of Ethiopia, Benin, Nigeria and Bangladesh. All four projects are market-based initiatives, but are diverse in regards to the project owners, namely, an international non-governmental organization (NGO), a multinational corporation (MNC), a local small and medium enterprise (SME) and a local farmer cooperative. We focus the investigation on distribution in the food sector because this sector has huge potential to improve food security and alleviate poverty (Da Silva et al., 2009). In addition, initiatives aiming to improve food security face numerous challenges related to distribution and marketing (Humphrey and Robinson, 2015). The focus is on a hybrid intermediary whose defining characteristics refer to "the centrality of a social and/or environmental mission, with its primacy over economic value creation" (Holt and Littlewood, 2015, p. 3). Hybrid intermediaries combine elements of several traditional types of organizations and operate in between two different organizational "architypes": the "traditional company" focused only on financial value creation and the "traditional not-for-profit organization" focused merely on social value creation (Battilana et al., 2012).

Our study contributes to the social supply chain sustainability literature in two ways. First, the study highlights a new category of non-traditional partners with a key role in driving

Distribution models at the base of the pyramid 
IJPDLM

49,5

494 social sustainability in supply chains - the hybrid intermediary organization. As such, the paper extends current studies which focus on NGOs as non-traditional partners (Rodríguez et al., 2016) and social businesses as focal actors in sustainable supply chains (Bals and Tate, 2017). Our inductive insights highlight how hybrid intermediaries can support firms to develop door-to-door distribution models while accounting for social issues. Second, our study extends the research stream on supply chain design and the role of intermediary support flows (e.g. Bals and Tate, 2017; Carter et al., 2015). Hybrid intermediaries provide several types of support flows essential for achieving socially sustainable distribution models, namely, knowledge sharing between local and global partners. Moreover, by acting as guardians of the mutual value creation approach, these hybrid intermediaries enable a new type of support flow - social values and mindset. These flows are essential for achieving truly sustainable supply chains as proposed by Montabon et al. (2016).

The paper continues with a literature review while the third section discusses the research methodology in more detail. The main insights for each project are described in the fourth section, while the fifth section synthesizes the key findings and develops propositions. The discussion of the results continues with the conclusion of the study which summarizes the main contributions, acknowledges limitations and provides avenues for further research.

\section{Literature review}

\section{Distribution models in BoP markets}

BoP markets refer to the largest target market in the economic pyramid frequently defined based on income indicators such as annual purchasing power parity or daily income threshold (see Rangan et al., 2011 for a detailed segmentation and sizing of the market). The literature on supply and value chains in BoP markets is in very early stages and there are important research gaps with crucial managerial relevance to be investigated. Specific topics investigated in this area include the impact of institutional voids on the creation of legitimacy (Parmigiani and Rivera-Santos, 2015), partner selection and relationship management (Hahn and Gold, 2014), inclusion of impoverished farmers across value chain activities (Hall and Matos, 2010), design of source, make and deliver processes (Bendul et al., 2016), network structures in BoP markets (Rivera-Santos and Rufin, 2010), NGOs initiatives to enhance poverty alleviation through supplier development programs (Rodriguez et al., 2016), lessons from social businesses on supply chain sustainability (Bals and Tate, 2017) and sustainability considerations (Brix-Asala et al., 2016; Gold et al., 2013).

Based on the literature, three main typologies of distribution models in informal BoP markets can be distinguished. First, there are the locally embedded, small-scale distribution models including street vendors and mom-and-pop shops. The street vendors also called mobile vendors do not have a fixed spot, nor a loyal customer base and sell limited range of products which results in low revenues. The mom-and-pop shops represent the traditional last mile retail shops and are "ubiquitous retailers ranging from streets stands and kiosks to corner stores" (Diaz et al., 2007, p. 71). These are frequently small-scale stores in urban or rural locations, offering high convenience for the consumers and suitable for products with high demand (Chopra and Meindl, 2013). These mini-stores dominate the retail environment in megacities in emerging economies. Subsequently, recent research explores supply and channel strategies for this retail channel in order to advise policy makers on urban logistics design and private sector on the design of commercial city logistics operations (Blanco and Fransoo, 2013). Second, there are distribution models based on local delivery teams, namely, networks of micro-entrepreneurs (Brugmann and Prahalad, 2007). These local delivery teams distribute products either to the village (direct-to-village) or to individual consumers (door-to-door). This type of distribution model requires significant investments in training and education, but it enables local economic development through employment of micro-entrepreneurs (Neuwirth, 2014). Additionally, it addresses gaps in local infrastructure, allows to control and lower inventory costs and is 
valuable especially when products are unknown to consumers (Neuwirth, 2014). Third, there are distribution models based on partnerships also known as "piggybacking." In this case, an already existing distribution network is used in order to decrease overhead costs and increase probability of success (Neuwirth, 2014). Since distribution to rural areas can be financially infeasible for numerous enterprises, partnerships can enable the development of a joint infrastructure to cut down the distribution expenses (Dogra, 2010). Most common partnerships are between NGOs and private initiatives in the form of MNCs, SMEs or micro-enterprises. While this model entails important economic benefits, the social aspects of managing the partnerships as well as the lack of direct access to consumer insights can jeopardize the longterm viability of the distribution model (Neuwirth, 2014).

In a review of supply chain configuration of BoP products, Bendul et al. (2016) found that successful distribution models tend to employ a mix of locally embedded channels and often combine physical flows with education and awareness campaigns for rural consumers. Yet, it is not clear how firms can design distribution models while balancing cost optimization goals with social issues, vulnerabilities and institutional voids inherent to the BoP markets.

\section{Intermediary organizations in $\mathrm{BoP}$ markets}

Literature suggests three main intervention levels of intermediaries in $\mathrm{BoP}$ initiatives, namely on the enterprise level (micro) through direct support to enterprises; on the supply chain level through supporting and connecting various supply chain actors; and on the market level (macro) through general market development activities (see Figure 1).

On the enterprise level, several authors recognize the significance of intermediaries in capacity building through training and consulting (Dutt et al., 2016), improving "skill adequacy" (Li et al., 2008) and providing "advanced, sequentially ordered, behavior-oriented knowledge structures used to create new ventures" - what the literature calls "expert venture scripts" (Smith et al., 2016, p. 910). Building social capital reinforces capacity building because social interactions with experts accelerate learning and the implementation of "expert venture

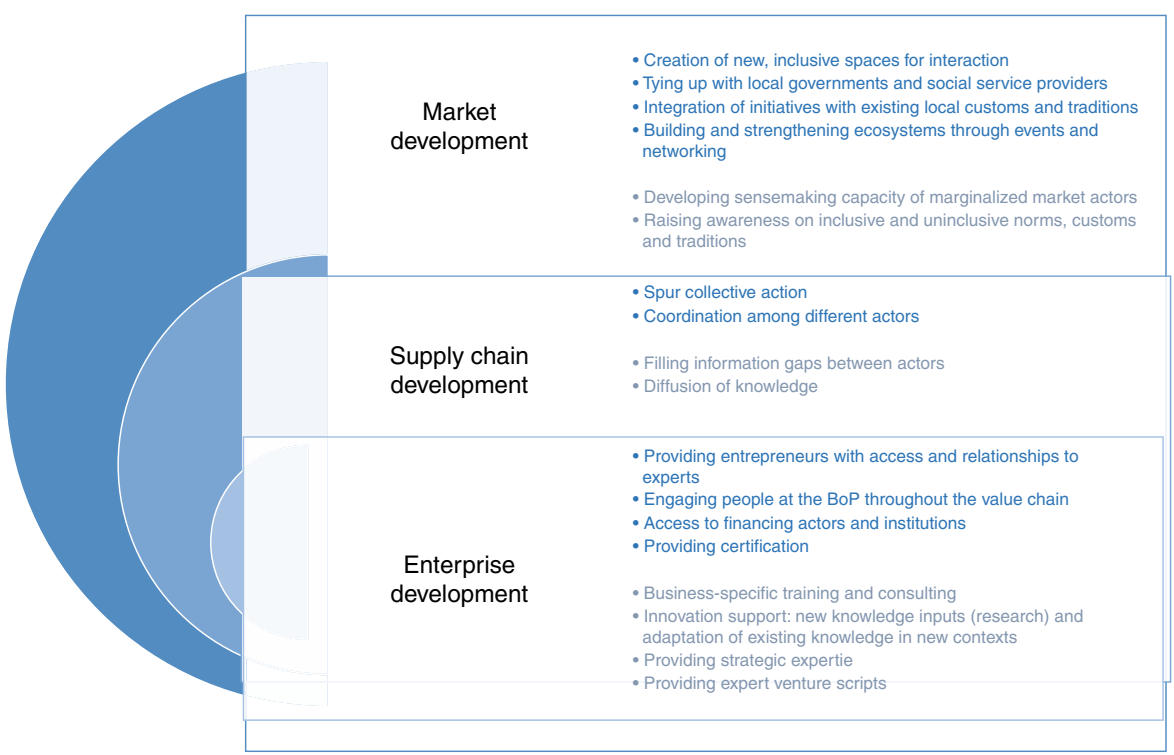

Sources: Own summary based on Clarke and Ramirez (2014), Chliova and Ringov (2017), Dutt et al. (2016), Kistruck et al. (2013), Li et al. (2008), Mair et al. (2012) and Smith et al. (2016)
Distribution models at the base of the pyramid
Figure 1. Contributions of intermediary organizations for initiatives in $\mathrm{BoP}$ markets 
IJPDLM

49,5

496

scripts" (Kistruck et al., 2013; Smith et al., 2016). Beside reinforcement of learning, the intrinsic value of social capital is also undoubtable, as it is seen as one of the most valuable assets of enterprises at the BoP (Smith et al., 2016). Besides, one set of intermediary skills called "enabling" (Clarke and Ramirez, 2014) - or in other words, providing new knowledge inputs and adapting existing knowledge in different contexts - is especially important at the micro level because it can help enterprises to create and launch innovations.

On the supply chain level, intermediaries support capacity and network building. Three of the most influential intermediary skills which enable them to contribute to the development of supply chains are: "accessing" - connecting actors, "diffusion" of knowledge and "coordination" between several actors for joint agendas (Clarke and Ramirez, 2014). By connecting entrepreneurs to experts (Smith et al., 2016) and providing certification of quality (Li et al., 2008), intermediaries can add to this "asset" of enterprises. Simply introducing $\mathrm{BoP}$ ventures to other actors in the ecosystem can also be a large contribution to the success of these enterprises. For example, many intermediaries help $\mathrm{BoP}$ ventures to connect to investors and help to tackle one of the main challenges of $\mathrm{BOP}$ ventures: "inadequate financial access" (PPP Lab Food and Water, 2015, p. 24). Besides, numerous authors emphasize their role in helping to harness the collective action of groups of actors in the same level of a supply chain (Clarke and Ramirez, 2014). Intermediary organizations are also active in engaging with people in the supply chain and this supports successful template development at the BoP (Chliova and Ringov, 2017).

Finally, because $\mathrm{BoP}$ ventures operate in contexts with severe institutional voids, in order to support their missions, intermediaries need to actively engage in interventions on the market level (Mair et al., 2012; Smith et al., 2016). These market development efforts aim to create an enabling market environment, for example through the provision of financial capital and physical space for entrepreneurs (Dutt et al., 2016). Besides filling in gaps in the market to support entrepreneurs, in some cases intermediary organizations also aim to create change in the cultural environment. This is due to the fact that certain social norms at the BoP can prevent the success of inclusive business initiatives. Based on practices in microfinance in Bangladesh, Mair et al. (2012) specified ways through which intermediaries can contribute to an enabling social and cultural environment. One is "redefining market architecture" (for example through creating new spaces for interaction with often excluded actors) and the other is "legitimating new market actors" (for example through combining or recombining inclusive norms with traditions) (Mair et al., 2012). On the macro level, intermediaries also facilitate events and networking to build and strengthen existing ecosystems in BoP markets.

\section{Social impact creation in base of the pyramid markets}

The dual aim of $\mathrm{BoP}$ ventures is understood as simultaneously generating profit and creating positive social impact (London et al., 2010). While there is a general understanding on measuring profitability, there is no common agreement on the meaning and measurement of positive social impact such as poverty alleviation (Clark et al., 2004; Tate and Bals, 2018). Social impact is used and understood in many ways not only by practitioners (Clark et al., 2004) but also by scholars (White, 2010). The different definitions of social impact fall into the following three lines of thinking. Some scholars understand it as the broad, far-reaching results of social intervention (Liket, 2014; IMWG, 2014); others define it as the occurred social change which is proven to be attributed to the intervention (Clark et al., 2004), while other authors highlight the aspect of sustainability, explaining impact as the effects of social intervention which are sustained changes on people, organizations, environments and systems (Liket et al., 2014). Furthermore, impact has many forms and faces: literature differentiates between direct and indirect, intentional and unintentional, mission driven and public good impact (Liket, 2014). Efforts to assess social impact of BoP initiatives include the system of metrics developed by the global impact investing network (Barmeier and Simon, 2010) and the impact assessment tool of London (2009) who draws on 
insights from the capabilities approach of Sen (1999). Yet, tools and techniques for systemlevel assessment of social (and ecological) impact remain scarce (Hart et al., 2016).

As an attempt to clarify the understanding of terms in social impact creation, the impact measurement working group used insights from the literature to build their impact value chain (IVC) model (IMWG, 2014) (see Figure 2). IVC is a widely used model and although different authors define impact differently in their own understanding of the IVC, there is a more general agreement on the definitions of inputs, activities, outputs and outcomes. In the IVC presented below, impact is defined as "changes or effects on society or the environment that follow from outcomes that have been achieved" (IMWG, 2014, p. 6). This is not the most rigorous definition of impact because it does not mention attribution to the studied intervention as a criterion, as opposed to the definition of Clark et al. (2004) who describe impact as "the portion of the total outcome that happened as a result of the activity of the venture, above and beyond what would have happened anyway" (Clark et al., 2004, p. 7). Nonetheless, in order to assess impact in this sense, a counterfactual is needed which is often lacking in practice (Ebrahim and Rangan, 2010; White, 2010).

Changes which are further on the right of the IVC are more far-reaching, wide and they usually occur after a longer time period. When moving from activities to impacts, the actor whose activities are assessed is in less control of the results. Consequently, the further we move on the IVC, the more difficult it becomes to observe, understand, measure and attribute the changes resulting from one's activity. Despite such difficulties, some argue that in order to create better evaluations, practitioners need to move further on the IVC from measuring outputs and outcomes to measuring impact (Ebrahim and Rangan, 2010).

\section{Research gap and objectives}

The emerging literature of supply chain in $\mathrm{BoP}$ settings acknowledges the role of unconventional partnerships in bringing products and services to $\mathrm{BoP}$ consumers. Moreover, some studies show that these types of unconventional partners can often take vital roles in the reconceptualization of supply chains (Hahn and Gold, 2014; Gold et al., 2013). Intermediaries can support the development and effectiveness of particular types of distribution networks which rely on informal micro-entrepreneurs (Tang, 2016). In this study, we explore how partnerships with hybrid intermediary organizations can serve as mechanisms to overcome institutional voids and ensure effective reach of geographically scattered BoP consumers. The focus of this study is to investigate how intermediaries support BoP initiatives to design distribution models in informal markets, to overcome institutional barriers and to facilitate social impact creation. Bals and Tate (2017) investigate the support mechanisms of intermediaries in designing supply chains of social businesses, with a focus on microfinance institutions as intermediaries and financial flows. In this study, we focus on distribution stage of the supply chain, hybrid intermediaries and knowledge flows. Knowledge flows are



Source: IMWG (2014, p. 6)
Distribution models at the base of the pyramid 
IJPDLM

49,5

498 essential in BoP markets because the knowledge-driven types of value chains are most likely to create social impact (Ansari et al., 2012). Although there are growing number of academic papers about intermediaries, the mechanisms of how they enable social value creation through BoP supply chains are not well understood yet. Understanding social value creation is important in $\mathrm{BoP}$ settings because $\mathrm{BoP}$ initiatives often pursue strong social objectives. Therefore, the overarching goal of this study is to understand how intermediaries intervene at different levels of distribution networks in BoP markets and how (if) this results in social value creation.

\section{Methodology}

Research strategy: embedded case study

In this research, a case study strategy is applied because the goal is to better understand "a contemporary phenomenon within its real-life context" (Yin, 1994, p. 13). Considering the high context specific role of intermediary organizations, the holistic approach of the case study method is beneficial as it allows for an extensive study of contextual information. The chosen design is an embedded case study design which allows for in-depth, detailed examination of an example of the unit of analysis and the "subunits" (Eisenhardt, 1989). The main unit of analysis is the intermediary organization: BoPInc, and the clearly distinguishable subunits are four projects in the food sector where the main interventions are at the customer interface, namely, marketing and distribution. The focus of the study is on the interventions of the case organization in four different project-settings. This embedded design is valuable since it allows for comparison of the different roles fulfilled by the same actor in different contexts.

\section{Research context: marketing and distribution in the food industry}

The decision to focus on distribution in the food industry was driven by several important factors. First of all, large portions of the world population still do not have access to nutritious food products (Humphrey and Robinson, 2015). Second, many development initiatives focus on the smallholder farmers and the supplier interface of food processing businesses (Da Silva et al., 2009, p. 9). These types of interventions aim to improve the livelihoods of smallholder farmers by enhancing productivity and quality. However, development efforts also need to focus on the "other end" of the supply chain: the value chain of food processors and their consumer interfaces - distribution. Finally, in spite of the practical relevance of distribution at the $\mathrm{BoP}$, the "literature on distributing products or services in rural areas of developing countries is rather scant" (Tang, 2016, p. 128). Therefore, by focusing our study on distribution in the food sector, we aim to fill in an important research gap with high practical relevance.

\section{Case selection}

The hybrid intermediary selected for this study is BoPInc, an independent foundation founded in 2010 by a consortium of non-profit organizations in Utrecht, the Netherlands. BoPInc advocates the concept of inclusion and connects actors from various sectors in order to help them to explore and implement inclusive business strategies. This intermediary has been selected for this study for several reasons. First, the impact of the institution can be gauged from its significant growth. In its first year, the BoPInc team consisted of several experts in the Netherlands. By 2016, the organization had 29 employees in its main office and numerous team members spread around the world in Kenya, Ethiopia, Nigeria and Bangladesh. Second, BoPInc has extensive expertise in BoP distribution models, this being one of the three main pillars around which the foundation organizes its services. Third, BoPInc is a hybrid intermediary - it works as a social enterprise and its revenues come from public (55 percent in 2016), private-public partnerships (PPPs) (35 percent) and private funding (10 percent) from various projects related to inclusive business in $\mathrm{BoP}$ markets (BoP Innovation Center, 2017). The chosen intermediary organization is representative for 
intermediary activity in BoP markets due to its starting point as a donor initiative and its evolution into a project-based enterprise.

To select the subunits, a database was created about past and ongoing projects of BoPInc including some of the main project characteristics: goal, partners (sectors) involved, BoPInc's role (main activities), location, donors, industry, start date and end date. The focus was narrowed down to projects in the agro and food industry, where BoPInc's main activities are related to marketing and distribution. The final selection of the four projects was done by considering two main factors (see Table I). First, the chosen projects must have been running for multiple years which would enable a better insight into the outcomes of project activities. Second, chosen projects had to have been monitored and evaluated which meant project outcomes were known to BoPInc.

One of the main differences between the projects is the background of the main (implementing) partner of BoPInc. In two projects, BoPInc worked closely with local food processors: a small, semi-industrial farmer cooperative in Benin and a medium-sized Ethiopian company. In Shakti+, the main partner and the project lead is a multinational giant in fast moving consumer goods. In Profitable Opportunities for Food Security (PROOFS), the main implementing partner is an international NGO. This diversity allows us to explore dynamics and interventions of various types of partnerships and governance structures.

\section{Data collection and analysis}

The data collection procedure adheres to principles of triangulation by building on multiple sources to strengthen construct validity (Yin, 1994). In the first step, several expert meetings were conducted to complement the insights gained from the literature review and refine the interview guide developed based on a priori theoretical constructs. Data collection on the four cases started with desk research including public information on the projects and internal confidential project files (e.g. proposals, monitoring and evaluation reports) (see Table II).

Primary data were collected through semi-structured interviews with employees of the intermediary organization who were involved in the projects. This method supported consistency and comparability of data between the cases and also allowed for flexibility to find information about relevant topics and contextual elements beyond our guiding questions and a priori constructs. The interviews followed an a priori developed interview guide as well as project-specific questions prepared based on secondary data collection. As an example, in the case of Guts Agro, a project-specific question was raised about the recruitment process and eligibility criteria to become a sales agent in the newly created distribution network. This question was added in order to gain more insights on the target group which could benefit from this economic opportunity by joining the network. Through interviews, information cross-checks were conducted between interviewees to

\begin{tabular}{|c|c|c|c|c|c|}
\hline PPP & Main financing body & $\begin{array}{l}\text { Project } \\
\text { name }\end{array}$ & Main partner of BoPInc & Location & $\begin{array}{l}\text { Project } \\
\text { years }\end{array}$ \\
\hline \multirow[t]{2}{*}{ 2SCALE } & $\begin{array}{l}\text { Dutch ministry of foreign } \\
\text { affairs }\end{array}$ & CTAE & $\begin{array}{l}\text { CTAE (Beninese Farmer } \\
\text { cooperative) }\end{array}$ & Benin & $\begin{array}{l}2014- \\
2016\end{array}$ \\
\hline & $\begin{array}{l}\text { Dutch ministry of foreign } \\
\text { affairs }\end{array}$ & GUTS & $\begin{array}{l}\text { GUTS Agro Industry PLC } \\
\text { (Ethiopian food processor company) }\end{array}$ & Ethiopia & $\begin{array}{l}2014- \\
2016\end{array}$ \\
\hline AIM & $\begin{array}{l}\text { Unilever, Dutch ministry } \\
\text { of foreign affairs }\end{array}$ & Shakti+ & $\begin{array}{l}\text { Unilever (Global MNC and its } \\
\text { Nigerian subsidiary) }\end{array}$ & Nigeria & $\begin{array}{l}2015- \\
2017\end{array}$ \\
\hline PROOFS & $\begin{array}{l}\text { Embassy of the Dutch } \\
\text { Kingdom in Bangladesh }\end{array}$ & $\begin{array}{l}\text { PROOFS } \\
\text { nutrition }\end{array}$ & $\begin{array}{l}\text { ICCO (Bangladeshi office of an } \\
\text { International NGO) }\end{array}$ & Bangladesh & $\begin{array}{l}2013- \\
2017\end{array}$ \\
\hline
\end{tabular}

Distribution models at the base of the pyramid 


\section{IJPDLM} 49,5

\section{0}

Table II.

Data sources

\begin{tabular}{|c|c|c|}
\hline $\begin{array}{l}\text { Type of data } \\
\text { source }\end{array}$ & $\begin{array}{l}\text { Case and } \\
\text { subunits }\end{array}$ & Number of sources used \\
\hline \multirow{5}{*}{$\begin{array}{l}\text { Publicly available } \\
\text { sources }\end{array}$} & BoPInc & 3 (annual report 2015 and 2016, website) \\
\hline & CTAE & 3 (website 2SCALE.org, 1 2SCALE report, 1 project page, 1 blogpost) \\
\hline & GUTS & $\begin{array}{l}5 \text { (1 2SCALE report, } 1 \text { interview, } 1 \text { project webpage, } 1 \text { company website, } 1 \\
\text { blogpost) }\end{array}$ \\
\hline & $\begin{array}{l}\text { PROOFS } \\
\text { nutrition }\end{array}$ & $\begin{array}{l}8 \text { ( } 2 \text { blogposts on BoPInc's website, } 2 \text { blogposts on ICCO's website, } 2 \\
\text { websites of private partners, } 1 \text { report from the Bangladesh Bureau of } \\
\text { Statistics, } 1 \text { publication from PROOFS) }\end{array}$ \\
\hline & Shakti+ & 4 (website of GAIN, 1 website of Unilever, 2 online journal articles) \\
\hline \multirow{5}{*}{$\begin{array}{l}\text { Confidential } \\
\text { documents }\end{array}$} & BoPInc & 3 \\
\hline & CTAE & 4 \\
\hline & GUTS & 5 \\
\hline & $\begin{array}{l}\text { PROOFS } \\
\text { nutrition }\end{array}$ & 6 \\
\hline & Shakti+ & 4 \\
\hline \multirow{5}{*}{ Interviews } & BoPInc & 1 (personal with the CEO in Utrecht) \\
\hline & CTAE & $\begin{array}{l}2 \text { (personal with the project lead in Utrecht, Skype with the project manager } \\
\text { in Benin) }\end{array}$ \\
\hline & GUTS & $\begin{array}{l}2 \text { (personal with the project lead in Utrecht, Skype with the project manager } \\
\text { in Ethiopia) }\end{array}$ \\
\hline & $\begin{array}{l}\text { PROOFS } \\
\text { nutrition }\end{array}$ & 2 (personal with a former project manager and a project officer in Utrecht) \\
\hline & Shakti+ & $\begin{array}{l}2 \text { (personal with the project manager, Skype with an independent } \\
\text { consultant) }\end{array}$ \\
\hline
\end{tabular}

ensure validity. Each interview lasted between 30 and $60 \mathrm{~min}$. After the interviews, for all cases, additional information was received through several follow-up questions either personally or via e-mail. Interviews were recorded and extensively summarized (one interview could not be recorded due to technical problems). For data analysis, the tactic of using dimensions suggested by existing literature to look for "within-group similarities coupled with intergroup differences" was used (Eisenhardt, 1989, p. 540). The dimensions employed followed the IVC model dimensions and analytical constructs based on the BoP literature (see Table III).

Therefore, as described above, the study adhered to criteria of internal validity, construct validity, external validity and reliability criteria (Gibbert et al., 2008) (see Table IV).

Impact value chain model

dimension

Analytical constructs

Input, activities and outputs Enterprise, supply chain and market development interventions of the intermediary (with a focus on distribution stage of the supply chain)

Outcomes Overcoming institutional voids Locally relevant value propositions Affordable products and services Acceptability and availability (geographic reach)

Table III.

Impact value chain model - dimensions Impact and analytical constructs
Sustainability and resilience

Capabilities enhancement, social capital

Local embeddedness 
Methodological

\begin{tabular}{lll} 
aspect & Tactic Description \\
\hline
\end{tabular}

Internal validity Research framework derived from literature Pattern matching Theory triangulation

Construct validity

Data triangulation Review of transcripts by key informants Chain of evidence Explanation of data analysis procedure

External validity

Reliability Case study protocol and

\section{Nested approach to} cross case analysis Case study background Replication logic

Analytical constructs employed draw on theoretical insights from the impact value chain model and the role of intermediaries in social value creation

Using the analytical constructs, similarities within the groups and differences between the groups were identified (Eisenhardt, 1989) Combination of primary and extensive secondary data

Secondary data collected was structured in a database, following the guiding questions

Cross-checking of facts and information between interviewees, during the data collection

Member checks conducted after the data collection to avoid misinterpretation or misunderstandings (Shenton, 2004)

One unit and four subunits of analysis

All four projects are market-based initiatives (compare), but have

different governance structures (contrast)

Thick project description in the case file and detailed case background provided in the findings database
The data collection was conducted according to a set of guiding questions following the analytical constructs and project-specific highlights

Development of a case study database with all data sources
Distribution models at the base of the pyramid

501

Table IV.

Research design aspects based on Gibbert et al. (2008)

\section{Findings}

This chapter outlines main insights gained from each of the four projects and the interventions of the intermediary, based on the analytical constructs outlined by the IVC model.

\section{Shakti+ - learning about facilitating tensions between social and economic priorities}

The Shakti+ program aimed to combine the classic door-to-door sales model of food and hygiene products with additional educational and behavioral change messages to the target group. As part of the program, a total of 1,000 Shakti women were recruited and trained as sales personnel in the summer of 2015 across four states in Nigeria. The sales agents were village women between the age of 25 and 45 , with basic literacy and proven entrepreneurial attitude.

Input, activities and outputs. The main part of BoPInc's activities was related to its facilitator role: organizing workshops, conducting field visits, facilitating frequent communication between the partners (consisting of international and local NGO, an MNC, a consulting firm and an IT start-up). As the project manager from BoPInc described: "it was a collection of partners with very different backgrounds, very different profiles, and [...] I think Unilever has a lot of experience with partnerships compared to other multinationals, and they acknowledged the fact that a sort of independent intermediary is quite crucial." Besides facilitation, BoPInc provided general advisory and inputs to support the development, implementation and review of the project strategy. At a later stage, BoPInc also engaged in marketing activities by contributing to the development of promotional materials. Yet, the complex organizational structure of the project posed challenges from the early stages. The diverse consortium required an independent intermediary to act as a mediator to balance economic and social priorities.

Outcomes and impact. In regard to outcomes, BoPInc participated in the content development of the campaigns. Therefore, changes in product acceptability are relevant outcomes of project activities, particularly due to the focus on behavioral change. Awareness about the importance of preventing iron deficiency was found to be high among 
IJPDLM 49,5

502 consumers of the Shakti+ program. Almost two thirds of the Shakti+ respondents who participated in the survey were aware of the importance of iron consumption. In contrast, less than two fifths of the general population which did not participate in the program was aware of the importance of iron sufficiency.

In regard to the impact created, the Shakti+ project directly impacted two main beneficiary groups. First, the project reached a significant number of BoP consumers. During the first pilot, Shakti+ ladies reportedly sold Unilever products to more than 26,000 households on average each week (surpassing the goal of reaching 20,000 households weekly). Furthermore, Unilever's track record achieved with the original Shakti program is a promising sign for its capacity to expand and sustain Shakti+ in Nigeria and in other countries which have BoP market segments. Second, the project had an impact on the microentrepreneurs - the Shakti+ women. Yet, our findings highlight some controversy regarding the satisfaction of the female micro-entrepreneurs. While one group valued the extra educational work next to product sales, others felt that the educational component was additional work and that they were not compensated adequately for their efforts. This dissatisfaction was reflected in numerous dropouts. The project manager referred to this as one of the key learnings after the 1st pilot: "They started to complain: 'Why should I do that? It doesn't bring me more money!' and rightly so, they raised the question [...] so that was a sort of wake-up call that anything you want the ladies to do additionally to selling [...], you have to compensate, or you have to incentivize them well." Overview of the main findings for this case can be found in Table V.

\section{PROOFS nutrition: learnings about formal and informal missions}

PROOFS is a PPP aiming to improve the lives of 80,000 rural households living under the poverty line in North-West and South-West regions of Bangladesh. The project started in 2013 and was designed to support the smallholder families in their agricultural activities, develop their access to water and sanitation and improve their hygiene and nutrition status.

Input, activities and outputs. In this project, BoPInc's main role was to develop and implement a delivery strategy through a Nutrition Sales Agent (NSA) network of microentrepreneurs who deliver nutritious products and educate the target communities on nutrition and hygiene. Local partners recruited and trained 320 women to work as NSA. Given the knowledge that the accessibility of products is alone not sufficient to achieve

\begin{tabular}{|c|c|}
\hline & Shakti+ \\
\hline Main goal & $\begin{array}{l}\text { Promote positive nutritional and health behavior and enhance the effectiveness of } \\
\text { the distribution network to ensure high customer reach for Unilever products }\end{array}$ \\
\hline \multirow[t]{2}{*}{$\begin{array}{l}\text { Input, activities and } \\
\text { outputs - intermediary } \\
\text { interventions }\end{array}$} & $\begin{array}{l}\text { Supply chain development: capacity building, marketing strategy development, } \\
\text { implementation support for the Shakti+ distribution model, partnership } \\
\text { facilitation and mediation }\end{array}$ \\
\hline & $\begin{array}{l}\text { Enterprise development: advisory services, input for the development of the } \\
\text { project strategy }\end{array}$ \\
\hline \multirow[t]{2}{*}{ Outcomes } & Increased availability and acceptability of the product. \\
\hline & Increased awareness for nutritional messages and increased demand \\
\hline \multirow[t]{2}{*}{ Impact } & $\begin{array}{l}\text { Improved skills of micro-entrepreneurs (through capacity building), recognition in } \\
\text { the communities and families of the women micro-entrepreneurs }\end{array}$ \\
\hline & $\begin{array}{l}\text { Behavioral change through behavioral messages and nutritional products for } \mathrm{BoP} \\
\text { consumers }\end{array}$ \\
\hline \multirow{2}{*}{$\begin{array}{l}\text { Project-specific } \\
\text { highlights }\end{array}$} & Tensions between priorities of the business and social sector \\
\hline & $\begin{array}{l}\text { Trade-offs between cost effectiveness and implementation of educational elements } \\
\text { Importance of the value proposition for micro-entrepreneurs in the sales network }\end{array}$ \\
\hline
\end{tabular}

\section{Table V.}

Highlights for the Shakti+ project 
impact goals, major emphasis was placed on behavioral change messaging. Apart from counseling sessions to households and educational group sessions (courtyard sessions), BoPInc developed innovative tools which the NSA implemented on the field to foster behavioral change and create demand for their products. An example is the mobile movie session, in which NSA projected movies related to their messages. Toward the end of the project, improving the (economic) sustainability of the sales network and making it more beneficial from the NSA's perspective became dominant in the mission of BoPInc (and the personal mission of the interviewees).

Outcomes and impact. Regarding outcomes, the project achieved increased geographic availability, acceptability and awareness on basic hygiene and nutritional knowledge on beneficial products. The impact of BoPInc on NSA delivery model was manifold: driving the process of improving the model by strategic suggestions, knowledge inputs to NSA trainings and small-scale data collection to find out the biggest challenges and rooms for improvement in the model. The most quantifiable impact related to the NSA is the income growth of the female entrepreneurs. NSA sales were reported to be growing through the course of the project, and the female entrepreneurs reported to be satisfied with the additional income to their households. Besides income growth, indicators of NSA's development as entrepreneurs and the improvement of their social status (as revealed by focus groups and success stories) were additional impacts. The BoPInc project officer shared one of her experiences from focus group discussions: "Then I asked them to show how their husbands feel about their work now and they all pointed to the happier part of the scale and showed a huge difference. [...] Because from the moment the money starts to come in, the husbands start to appreciate their work." The former program manager highlighted the exceptionally low dropout rates among the NSA (less than 10 percent). Toward the end of the project, nearly all NSA expressed their intention to continue with their activities.

Furthermore, market studies showed that customers appreciated the convenience of the distribution model. The special events for behavioral messaging, especially the mobile movie sessions (initiated by BoPInc) were extremely popular in the community. Relaxed control of the NSA by the project management enabled some NSA to develop new entrepreneurial skills by developing new sales tactics independently. However, the lack of control also had unintended consequences. The project officer remembers: "We noticed that some NSA started selling cigarettes and chocolate [...] so then they received training and we put some constraints on what to sell. Of course, these products [such as cigarettes] should not be supported, and we as BoPInc would never support the distribution of these products either, but then from a business perspective, personally I find it in a way good that the NSA independently identified demand on the market." Overview of the main findings for this case can be found in Table VI.

\section{The 2SCALE projects - learnings about ownership}

Given their similar partnership context, two projects: CTAE and GUTS are described together in this section. These two projects are part of an overarching program, 2SCALE, which started in 2012 with the goal to scalePPPs in several focus countries in Africa. The first project, the Ethiopian GUTS Agro, produces a food supplement based on corn and soy, fortified with micronutrients and other nutritious foods based on maize and soybean. The second project CTAE is a farmer cooperative in a rural town in Benin which produces Soya Goussi, a by-product of processing soybeans into soya oil.

Input, activities and outputs. In the case of CTAE, BoPInc engaged in several activities: market research, developing and testing new packaging, developing promotion messages and launching marketing campaigns and designing kiosks to create more attractive sales points for Soya Goussi. The aim of the intervention was to increase the attractiveness and

Distribution models at the base of the pyramid 
IJPDLM

49,5

504

\section{PROOFS}

Main goal

Input, activities and

outputs - intermediary interventions

Education and distribution of nutritious food products to rural households Enterprise development: market research, strategy development, project

implementation support, connecting and engaging companies in nutrition sector, finding Dutch companies interested in piloting innovations in Bangladesh Supply chain development: support in the development of the door-to-door distribution model, recruitment and selection of local partners, training provision for women, educational group sessions, and integration of behavioral change tools in the distribution model

Market development: educational group sessions, counseling sessions at household level, development and implementation of innovative tools to foster behavioral change, connecting local with global partners

Outcomes Increased awareness on basic hygiene and nutritional knowledge Improved acceptability of products

Impact Improved dietary diversity, food adequacy, and others at household level Increase of income, social status and entrepreneurial skills for the women microentrepreneurs

High number of people reached (scale)

Importance of local presence

Indirect information flows and a long chain of intermediary actors can create tension Difference between considering sales agents as intermediary actors or as beneficiaries Project-specific
highlights
Table VI. the PROOFS nutrition project

accessibility of Soya Goussi in BoP markets. The first step for BoPInc was to engage in knowledge and capacity building: developing a common understanding on the concept of BoP consumers and on the importance of marketing. The project lead and the project manager both explained this as one of the main challenges of the collaboration: "we had to create a joint language [with CTAE] [...] which took some time." Toward the end of the collaboration, in preparing for exit, BoPInc also focused on expanding the marketing expertise and capacities within CTAE itself by appointing and training a cooperative member dedicated to marketing.

In the case of GUTS, the first set of activities was related to product development. After market research, BoPInc supported the development of a product called Supermom: a fortified corn and soy blend for low-income consumers. BoPInc had an important role in the package design and the overall product launch. Second, BoPInc assisted the implementation of a new distribution model. In order to directly reach the targeted customers and cut the extra margins of the "middlemen" from the price, the founder and CEO of GUTS Agro followed the recommendation of BoPInc team and decided to develop a door-to-door model (called LIKIE) in which sales women (LIKIE ladies) distribute the product on tricycles. He explained the decision in an interview published by BoPInc: "we chose LIKIE for several reasons, not in the least because it creates employment for women. The tricycles make their task easier, and customers take the 'LIKIE Ladies' more seriously when they have transport and uniforms. We were also looking for something we could scale out easily, so tricycles were clearly the best choice."

As the output of the second phase of the project, LIKIE ladies were recruited and trained. By the end of the project collaboration, more than 50 micro-entrepreneurs were actively selling products in semi-urban areas in five towns and the expansion to new towns has started. Both the project lead and the project manager emphasized the unique commitment of the leader of GUTS Agro: "They [the company] were really sincere with their ambition in going the extra mile to reach a lower segment." However, the entrepreneur became very "protective of the results" and there was "limited room" for BoPInc's advice toward the end of the project when the focus was on ensuring the long-term viability of the LIKIE model. 
Outcomes and impact. In the case of CTAE, the project lead perceived increased awareness as the most important direct outcome of the project. In terms of indirect outcomes, the quality of the product improved because the newly introduced packaging was not only varied in size and labeling, but it was also more hygienic. Reporting based on data from the field shows that the number of consumers reached grew by more than 33 percent between 2014 and 2016.

In the case of GUTS, the impact created through direct project outcomes can be regarded in terms of two aspects: appropriateness and affordability of the product for BoP consumers; and economic and social viability of the LIKIE distribution model. First, significant trade-offs between affordability and appropriateness of packaging and cost effectiveness had to be overcome. After the end of the pilot, a reach of over 30,000 households was reported, in new geographical areas with more nutritious products available. Moreover, the new distribution model creates space for dialog between women as entrepreneurs and consumers around nutrition. Second, apart from its potential to reach nutritional impact, the project created micro-entrepreneurship opportunities for more than 50 women without a job. Yet, there is some uncertainty in regard to the long-term commercial viability of the sales model. The micro-franchise model can only be sustainable if it offers sufficient income opportunities for the LIKIE ladies. The intermediary, BoPInc, suggested non-competitive products from other companies, which would also be beneficial for the target group and bring additional revenues for the sales agents. However, this suggestion has not been implemented by GUTS Agro. Overview of the main findings for this case can be found in Table VII.

\section{The role of intermediary organizations in driving social impact in BoP distribution models}

The role of intermediaries in BoP distribution models design and operation

Our findings show that intermediaries intervene at different levels of the supply chain to support focal firms in designing and operating decentralized distribution models to achieve high availability and accessibility of food products. As literature suggests, our embedded case study analysis illustrates how the intermediary engages in supply chain development (through coordination among different actors) to facilitate access to finance, transfer knowledge, develop and implement distribution strategy, monitor implementation, design packaging and facilitate direct access to products and "reach over" middlemen, thereby overcoming institutional voids. Also, our study highlights that several market development functions were delivered through other parties - "intermediaries of the intermediary" with strong local presence. As suggested by current studies (e.g. Mair et al., 2012), in several instances, BoPInc initiated and/or facilitated the outreach to external service providers for activities which required intimate knowledge on local systems and legitimacy, e.g. engaging with municipalities in Ethiopia to recruit LIKIE ladies in GUTS. It is this local presence that enables the creation of a locally relevant value proposition for the micro-entrepreneurs joining (or continuing) in the distribution network. Our findings show that the retention rates of micro-entrepreneurs are a key determinant of effectiveness of the distribution channel. In this sense, intermediaries can support firms to develop locally relevant value proposition for the micro-entrepreneurs in the network.

Our projects situated in different cultural backgrounds also illustrate that the value proposition for the micro-entrepreneurs in the distribution network may be dependent on the cultural context. For example, in the case of the GUTS project, the value proposition was related to sufficient income opportunities driven by the amount of products in their basket, while for the NSA ladies in Bangladesh, social status as perceived by their husbands and society was seen as a key benefit of joining the network. Our insights suggest that
Distribution models at the base of the pyramid 


\section{IJPDLM 49,5}

506
CTAE

GUTS
Marketing and distribution of nutritious foods for low-income customers

Market development: increase availability and access for $\mathrm{BOP}$ consumers, increasing awareness of $\mathrm{BoP}$ consumers characteristics Supply chain development: design and implementation of marketing and distribution approach

Enterprise development: capacity building, training, strategy development, implementation support

Outcomes

Impact

Project-specific highlights
Table VII.

Highlights for CTAE and GUTS projects
Increase in acceptability and awareness Developed appropriate product in terms of of the product

Improved appropriateness of product through higher quality and hygiene standards cutting margins to decrease consumer price

Significant sales growth and increase in reached people (scale)

Commitment of the management team illustrated through independent investments (sustainability)

Scarce internal capacities of CTAE Importance of local presence Importance of showcasing pilot results to foster adoption of pro-poor strategies social and cultural aspects

Improved affordability of products Improved availability of products for remote communities through the door-todoor distribution model marketing strategy development, lementation support, packaging design Market development: adoption of existing knowledge in new contexts

Continuous dialog between women entrepreneurs and consumers around nutrition (social capital and behavioral change)

Additional income of sales ladies through micro-entrepreneurship opportunities created by the project

Strong ownership of GUTS Agro

Importance of local presence

Trade-offs between affordability and acceptability

Profitability of micro-entrepreneurial activity in the sales network

micro-entrepreneurial distribution channels should be developed with a clear value proposition for the (female) entrepreneurs to account for social status, increased income (even if this means partnering with competitors) and incentives to join trainings and develop the entrepreneurial skills. These insights highlight specific aspects difficult to quantify, evaluate or even perceive while designing supply chains in BoP markets, as suggested by some sustainability scholars (Linton et al., 2007).

The design of traditional distribution networks focuses on aspects such as response time, product variety, product availability, customer experience and order visibility (Chopra, 2003). Our findings suggest that these aspects have a different meaning in the context of BoP distribution networks. For example, product availability aspects in informal BoP markets refer to overcoming infrastructural deficiencies and ensuring geographical availability of products in remote areas, while customer experience is focused on convenience, price and brand. Traditional perspectives and research on international distribution strategies and networks entail a predominant focus on location, capacity decisions, reconfiguration of networks, strategic alliances, consolidation of facilities and postponement (Olhager et al., 2015). Our study highlights a new perspective on global distribution networks with a focus on informal BoP markets. In this type of distribution models, soft issues are the ones most critical for success, namely managing diverse project partners, their expectations and social orientations, power dynamics, focus on local capacity building and local embeddedness. This study also reveals that the design and operation of decentralized, local distribution models in 
BoP markets requires formal and informal partnerships. While partnerships are very common mechanisms in traditional multi-echelon distribution structures, in informal BoP markets, the focus is on non-traditional partnerships with local NGOs and community associations who are known to have a strong social orientation. In these types of partnerships, a key insight relates to the continuous trade-off between social and economic aspects. As shown by the Shakti project, the conflict between business logic and the logic of the NGO presents real challenges. For the NGO partner, cost considerations of the campaign were not a priority, however, for Unilever lean operations and profitability were important. Our findings suggest that a pure economic logic as traditionally adopted in supply chain management does not fit $\mathrm{BoP}$ settings where social issues override economic issues. In this context, the role of independent intermediaries becomes essential in order to balance organizational mindsets, cultures, agendas and modes of operation.

With these insights, we contribute to the literature on social sustainability in supply chains. Previous studies have focused to a large extent on internal practices (e.g. safe working conditions - Pullman et al., 2009) and at times on external practices (e.g. stakeholder engagement for local communities development - Gimenez et al., 2012), NGOs as focal actors implementing traditional supplier development programs (Rodríguez et al., 2016) and social businesses as focal actors in sustainable supply chains (Bals and Tate, 2017). Our study extends this stream of literature by bringing focus into a new type of nontraditional partner in sustainable supply chains - hybrid intermediary. In addition, our insights highlight how non-traditional partners like hybrid intermediaries can support firms to develop local distribution networks based on micro-entrepreneurs and to account for social issues in these settings.

\section{Intermediaries and social impact in BoP distribution models}

This section discusses mechanisms and challenges for creating positive results for beneficiary groups through the interventions of intermediaries at different levels of $\mathrm{BoP}$ distribution networks.

Mechanisms of social impact creation in distribution networks through intermediary efforts. Based on our analysis, we suggest three main mechanisms through which intermediaries can enable social impact creation in BoP distribution networks: knowledge sharing and capacity building, network development and guardians of the mutual value creation approach.

First, intermediaries can provide access to knowledge inputs and strengthen skill building through training and coaching in order to overcome the gap between existing knowledge of different groups of stakeholders and skills of BoP entrepreneurs. Drawing on our findings and the literature, we suggest that mechanisms of knowledge sharing and capacity building are key aspects through which intermediaries can intervene in BoP value chains (Smith et al., 2016). As in the case of the 2SCALE projects and PROOFS nutrition, the $\mathrm{BoP}$ ventures showed plans to continue investment in their BoP business strategy and this shows that through knowledge sharing and capacity building, intermediaries can enable adoption of pro-poor strategies. An example is developing sense-making of marginalized groups and raising awareness on inclusive and not inclusive norms (Mair et al., 2012) for women in rural Bangladesh (PROOFS nutrition). This leads to the following proposition:

P1. The efforts of intermediaries in knowledge sharing and capacity building among partners enable the adoption of pro-poor strategies across the supply chain.

Second, through network building, intermediary organizations increase the potential for long-term economic viability and social impact of BoP supply chain strategies. Several examples show that through connecting and engaging actors, balancing power
Distribution models at the base of the pyramid 
IJPDLM

49,5 asymmetries, the intermediary had a positive contribution in increasing the potential for sustainability. For example, in the case of PROOFS, partnerships were created with suppliers of food and hygiene products, including local companies and multinationals. A partnership was created with JITA, a large local door-to-door distribution network, so that NSAs can also use the infrastructure of JITA (local hubs) to pick up products. Several examples illustrate how BoPInc could utilize its professional network and connections outside of the African and Asian economies in order to support ventures in these economies. For example, Unilever was involved in PROOFS nutrition as a supplier and an international organization was involved in financing the upgrade of CTAE's factory. Therefore, the following proposition emerges:

P2. The efforts of intermediaries in network building enable the long-term viability and social impact creation of BoP strategies across the supply chain.

Third, we propose that hybrid intermediaries are in the position to advocate the needs and requirements of $\mathrm{BoP}$ and therefore can act as guardians of the mutual value creation approach. Although in different ways, all projects show examples of how the intermediary stepped in to achieve "balance" between social orientation and business orientation. The case analysis suggests that the value added by the intermediary is not only a sum of outcomes of its deliverables, but also refers to "guarding" the mutual value creation perspective of balancing between goals and actors. Both in GUTS and in PROOFS nutrition, the intermediary proactively took the role of advocating the needs and the development of the sales ladies who were engaged in new door-to-door channels. Their efforts seemed to go beyond expectations or ambitions of other parties to have positive impact on the lives of the micro-entrepreneurs and to ensure the sustainability of the model by improving profitability for the ladies. Safeguarding of BoP micro-entrepreneurs is an essential task given that they can be perceived as "fringe stakeholders" (Hart and Sharma, 2004). Hybrid intermediaries, by safeguarding the interest of micro-entrepreneurs, can enable economic viability of the distribution network in the long-run as well as higher social impact creation:

P3. The efforts of hybrid intermediaries in advocating the needs of BoP can enhance social impact creation across BoP supply chains.

The three propositions suggest that hybrid intermediaries can contribute three types of support flows in order to design and operate distribution models based on microentrepreneurial networks in informal BoP markets. Thereby, our study contributes to the theory of supply chain (Carter et al., 2015) by illustrating new and diverse types of support flows provided by the hybrid intermediary - knowledge, bridging local and global partners, resources and capabilities. Moreover, by acting as guardians of the mutual value creation approach, these hybrid intermediaries enable a new type of support flow - social values and mindset. These flows might be essential for achieving sustainable supply chains. Both the knowledge-focused and social value-mindset flows can enable social impact creation (Ansari et al., 2012) and have the potential to challenge the roots of unsustainability in developing countries (Montabon et al., 2016).

Challenges of social impact creation through distribution models. Our embedded case study provides insights into the challenges of designing distribution networks in poverty settings with social issues in mind. First, significant social impact in the communities can be created through the combination of behavioral change and distribution. As such, distribution can ensure access to nutrition and food in remote locations, but also provide access to information on nutrition, sanitation and health. Yet, significant investments in training and capacity building are needed. Women-based distribution models present important trade-offs between cost effectiveness and implementation of behavioral change elements. These trade-offs 
illustrate the challenges of implementing a truly sustainable logic in supply chains and embracing the sequence of "first social, then economic sustainability," as proposed by Montabon et al. (2016). Moreover, trade-offs between cost effectiveness and impact provide further evidence for the difficulties encountered by firms to include BoP in supply chains as active economic value creators, for example distributors (Sodhi and Tang, 2014) as well as the challenges of creating value for all involved stakeholders (Lee and Tang, 2017).

Second, our findings suggest that a strong focus on social aspects is needed to retain the women in the distribution networks. Understanding how women perceive the benefits of joining/being in the network is essential to ensure scale and commercial success of these types of distribution models. Focus on social aspects is essential in this type of distribution model and can drive both economic and social sustainability. Social issues are difficult to quantify in supply chains (Linton et al., 2007). Yet, in this case, the outcome of managing these social issues is directly visible through the retention rates which are essential for the scale of the distribution model. Second, intermediaries supporting $\mathrm{BoP}$ ventures often engage in partnerships to expand their scope and this raises the issue of social impact attribution. Ebrahim and Rangan (2010) argue that attribution of such impacts to a single actor is only possible "where the organization has a near monopoly (through scale and scope) on the interventions in that location" (p. 29). The issue of attribution becomes even more pressing when social impact is delivered by "intermediaries of intermediaries of intermediaries." Moreover, the case of PROOFS shows how multiple levels of intermediation can result in complicated information flows, tensions and lack of control over the distribution model. The lack of control and accurate information flows pose accountability challenges for firms with global operations. Firms need to develop strong relational capabilities to ensure that they have both control and accountability over their supply chains (Parmigiani et al., 2011).

\section{Conclusion}

This study investigates an independent hybrid intermediary which provides business development services to BoP initiatives. Our embedded case study contributes with a different perspective on international distribution strategies, one focused on informal markets, non-traditional partners and soft issues. In these settings, trade-offs between cost effectiveness and social aspects are key decisions affecting the design and operation of distribution networks.

Our findings are subject to several limitations inherent to the research design as well as to the study of social impact creation and attribution. First, a wide definition of impact is adapted, which does not specify criteria for attribution. The purpose of this research is not to analyze the impact of the studied projects as a whole, but rather to explore how intermediaries in particular contribute to certain impacts. Second, the perspective of the intermediary is dominant in the collected data. To account for this limitation, triangulation was applied through the use of multiple data sources including third party evaluations, and in one project, an interview with an external consultant who participated in the project evaluation. Third, since our focal organization entails elements of hybridity, it is more likely that our findings apply to hybrid intermediaries.

Our study points to three important further research ideas. First, further research should investigate the antecedents of retention rates in women-based networks of micro-entrepreneurial distribution models. In particular, our insights highlight the importance of culture in understanding the retention rates in women-based networks of entrepreneurs. Further research can explore the influence of local socio-cultural factors on the retention rates in order to develop monetary and non-monetary incentive systems for joining and remaining in the network. Moreover, exploring the antecedents of retention rates in door-to-door distribution models could also benefit from a behavioral supply
Distribution models at the base of the pyramid 
IJPDLM 49,5 chain investigation. In this manner, BoP distribution networks can serve as an interesting research context to understand broader aspects of internal social sustainability, for example understanding what drives commitment of employees in supply chains (Carter and Liane Easton, 2011). Second, our study highlights a new type of support flow hybrid intermediaries can contribute to strengthen the social sustainability of distribution models in poverty settings - transfer of social values and mindsets. Further research can explore to what extent these support flows can drive social development outcomes and in particular the role of such flows in the transition toward the ecologically dominant logic (Montabon et al., 2016). Third, further in-depth studies of other intermediary organizations are needed to refine and test the insights gained in this study.

This study presents several recommendations in particular for firms aiming to design distribution models with social impact in BoP markets. First, developing partnerships with socially oriented intermediaries can ensure that the needs of vulnerable stakeholders are always represented. This is important from a long-term perspective: social capital in BoP markets can be translated in economic value in the long-run. Second, designing decentralized distribution models in $\mathrm{BoP}$ settings requires a strong, locally relevant and target-specific value proposition for the micro-entrepreneurs to join and remain motivated in the network. In this sense, intermediaries can support in increasing retention rates. Third, designing distribution (supply chains) models in informal markets requires a shared-value approach with the aim to improve profitability of value chain actors other than the enterprise (private sector actor) itself. This remains a key challenge because even for firms that are engaged in social initiatives, their own profitability remains the primary concern.

\section{References}

Ansari, S., Munir, K. and Gregg, T. (2012), "Impact at the "bottom of the pyramid: the role of social capital in capability development and community empowerment", Journal of Management Studies, Vol. 49 No. 4, pp. 813-842.

Bals, L. and Tate, W.L. (2017), "Sustainable supply chain design in social businesses: advancing the theory of supply chain", Journal of Business Logistics, Vol. 39 No. 1, pp. 57-79.

Barmeier, J. and Simon, J. (2010), "More than money: impact investing for development", Center for Global Development, Washington, DC, available at: www.cgdev.org

Battilana, J., Lee, M., Walker, J. and Dorsey, C. (2012), "In search of the hybrid ideal”, Stanford Social Innovation Review, Vol. 10 No. 3, pp. 50-55.

Bendul, J.C., Rosca, E. and Pivovarova, D. (2016), "Sustainable supply chain models for base of the pyramid", Journal of Cleaner Production, Vol. 162, pp. S107-S120.

Blanco, E. and Fransoo, J. (2013), "Reaching 50 million nanostores: retail distribution in emerging megacities", Beta Working Paper Series No. 404, Technische Universiteit Eindhoven, Eindhoven.

BoP Innovation Center (2017), “Annual report 2017”, available at: www.bopinc.org/updates/annualreport-2017-bopinc (accessed May 24).

Brix-Asala, C., Hahn, R. and Seuring, S. (2016), "Reverse logistics and informal valorisation at the base of the pyramid: a case study on sustainability synergies and trade-offs", European Management Journal, Vol. 34 No. 4, pp. 414-423.

Brugmann, J. and Prahalad, C.K. (2007), "Cocreating business's new social compact”, Harvard Business Review, Vol. 85 No. 3, p. 80.

Carter, C.R., Rogers, D.S. and Choi, T.Y. (2015), "Toward the theory of the supply chain”, Journal of Supply Chain Management, Vol. 51 No. 2, pp. 89-97.

Carter, C.R. and Liane Easton, P. (2011), "Sustainable supply chain management: evolution and future directions", International Journal of Physical Distribution \& Logistics Management, Vol. 41 No. 1, pp. $46-62$. 
Chliova, M. and Ringov, D. (2017), "Scaling impact: template development and replication at the base of the pyramid”, The Academy of Management Perspectives, Vol. 31 No. 1, pp. 44-62.

Chopra, S. (2003), "Designing the distribution network in a supply chain", Transportation Research Part E: Logistics and Transportation Review, Vol. 39 No. 2, pp. 123-140.

Chopra, S. and Meindl, P. (2013), Supply Chain Management: Strategy, Planning and Operation, Pearson Education, Upper Saddle River, NJ.

Clark, C., Long, D., Rosenzweig, W. and Olsen, S. (2004), "Double bottom line project report: assessing social impact in double bottom line ventures", available at: https://cloudfront.escholarship.org/ dist/prd/content/qt80n4f1mf/qt80n4f1mf.pdf (accessed January 30, 2018).

Clarke, I. and Ramirez, M. (2014), "Intermediaries and capability building in 'emerging' clusters", Environment and Planning C: Government and Policy, Vol. 32 No. 4, pp. 714-730.

Da Silva, C.A., Jenane, C., Baker, D.W. Shepherd, A. and Miranda-da-Cruz, S. (2009), “Agro-industries for development", available at: https://doi.org/10.1017/CBO9781107415324.004 (accessed January 30, 2018).

Diaz, A., Lacayo, J.A. and Salcedo, L. (2007), "Selling to 'mom-and-pop'stores in emerging markets”, The McKinsey Quarterly, Vol. 2 No. 1, pp. 71-81.

Dogra, B. (2010), Rural Marketing, Tata McGraw-Hill Education, New Delhi.

Dutt, N., Hawn, O., Vidal, E., Chatterji, A., McGAHAN, A. and Mitchell, W. (2016), "How open system intermediaries address institutional failures: the case of business incubators in emerging-market countries”, Academy of Management Journal, Vol. 59 No. 3, pp. 818-840.

Ebrahim, A. and Rangan, V.K. (2010), "The limits of nonprofit impact: a contingency framework for measuring social performance”, Social Enterprise Initiative, Harvard Business School, Vol. 8 No. 1, pp. 1-6.

Eisenhardt, K.M. (1989), "Building theories from case study research", Academy of Management Review, Vol. 14 No. 4, pp. 532-550.

Fawcett, S.E. and Waller, M.A. (2015), "Designing the supply chain for success at the bottom of the pyramid”, Journal of Business Logistics, Vol. 36 No. 3, pp. 233-239.

Gibbert, M., Ruigrok, W. and Wicki, B. (2008), "What passes as a rigorous case study?”, Strategic Management Journal, Vol. 29 No. 13, pp. 1465-1474.

Gimenez, C., Sierra, V. and Rodon, J. (2012), "Sustainable operations: their impact on the triple bottom line”, International Journal of Production Economics, Vol. 140 No. 1, pp. 149-159.

Gold, S., Hahn, R. and Seuring, S. (2013), "Sustainable supply chain management in "base of the pyramid' food projects - a path to triple bottom line approaches for multinationals?", International Business Review, Vol. 22 No. 5, pp. 784-799.

Hahn, R. and Gold, S. (2014), "Resources and governance in 'base of the pyramid'-partnerships: assessing collaborations between businesses and non-business actors”, Journal of Business Research, Vol. 67 No. 7, pp. 1321-1333.

Hall, J. and Matos, S. (2010), "Incorporating impoverished communities in sustainable supply chains", International Journal of Physical Distribution \& Logistics Management, Vol. 40 Nos 1/2, pp. 124-147.

Hart, S.L. and Sharma, S. (2004), "Engaging fringe stakeholders for competitive imagination", The Academy of Management Executive, Vol. 18 No. 1, pp. 7-18.

Hart, S., Sharma, S. and Halme, M. (2016), "Poverty, business strategy, and sustainable development", Organization \& Environment, Vol. 29 No. 4, pp. 401-415.

Holt, D. and Littlewood, D.C. (2015), "Identifying, mapping, and monitoring the impact of hybrid firms", California Management Review, Vol. 57 No. 3, pp. 107-125.

Humphrey, J. and Robinson, E. (2015), "Markets for nutrition: what role for business?”, IDS Bulletin, Vol. 46 No. 3, pp. 59-69.
Distribution models at the base of the pyramid 
IJPDLM 49,5
IMWG (2014), "Measuring impact subject paper of the impact measurement group", Impact Measurement Working Group, available at: https://doi.org/10.1038/nmat3063 (accessed January 30, 2018).

Karamchandani, A., Kubzansky, M. and Lalwani, N. (2011), "Is the bottom of the pyramid really for you", Harvard Business Review, Vol. 89 No. 3, pp. 107-111.

Kistruck, G.M., Beamish, P.W., Qureshi, I. and Sutter, C.J. (2013), "Social intermediation in base-of-thepyramid markets”, Journal of Management Studies, Vol. 50 No. 1, pp. 31-66.

Lee, H.L. and Tang, C.S. (2017), "Socially and environmentally responsible value chain innovations: new operations management research opportunities", Management Science., Vol. 64 No. 3, pp. 983-996.

Li, D., Eden, L., Hitt, M.A. and Ireland, R.D. (2008), "Friends, acquaintances, or strangers? Partner selection in R\&D alliances”, Academy of management journal, Vol. 51 No. 2, pp. 315-334.

Liket, K. (2014), "Why 'doing good' is not good enough. Essays on social impact measurement”, PhD dissertation, Erasmus University of Rotterdam, Rotterdam.

Liket, K.C., Rey-Garcia, M. and Maas, K.E.H. (2014), "Why aren't evaluations working and what to do about it: a framework for negotiating meaningful evaluation in nonprofits", American Journal of Evaluation, Vol. 35 No. 2, pp. 171-188.

Linton, J.D., Klassen, R. and Jayaraman, V. (2007), "Sustainable supply chains: an introduction”, Journal of Operations Management, Vol. 25 No. 6, pp. 1075-1082.

London, T. (2009), "Making better investments at the base of the pyramid", Harvard Business Review, Vol. 87 No. 5, pp. 106-113.

London, T., Anupindi, R. and Sheth, S. (2010), "Creating mutual value: lessons learned from ventures serving base of the pyramid producers”, Journal of Business Research, Vol. 63 No. 6, pp. 582-594.

Mair, J., Marti, I. and Ventresca, M.J. (2012), "Building inclusive markets in rural Bangladesh: how intermediaries work institutional voids”, Academy of Management Journal, Vol. 55 No. 4, pp. 819-850.

Montabon, F., Pagell, M. and Wu, Z. (2016), "Making sustainability sustainable", Journal of Supply Chain Management, Vol. 52 No. 2, pp. 11-27.

Neuwirth, B. (2014), "Marketing channel strategies in rural emerging markets”, working paper, Kellogg School of Management, Evanston, IL.

Olhager, J., Pashaei, S. and Sternberg, H. (2015), "Design of global production and distribution networks: a literature review and research agenda”, International Journal of Physical Distribution \& Logistics Management, Vol. 45 Nos 1/2, pp. 138-158.

Parmigiani, A. and Rivera-Santos, M. (2015), "Sourcing for the base of the pyramid: constructing supply chains to address voids in subsistence markets", Journal of Operations Management, Vol. 33 No. 1, pp. 60-70.

Parmigiani, A., Klassen, R.D. and Russo, M.V. (2011), "Efficiency meets accountability: performance implications of supply chain configuration, control, and capabilities", Journal of Operations Management, Vol. 29 No. 3, pp. 212-223.

PPP Lab Food and Water (2015), "Insight Series 03 - Partnerships for inclusive business development”, available at: www.snv.org/public/cms/sites/default/files/explore/download/partnerships_for_ inclusive_business_development.pdf (accessed May 24, 2019).

Prahalad, C.K. and Hammond, A. (2002), "Serving the world's poor, profitably", Harvard Business Review, Vol. 80 No. 9, pp. 48-59.

Pullman, M.E., Maloni, M.J. and Carter, C.R. (2009), "Food for thought: social versus environmental sustainability practices and performance outcomes", Journal of Supply Chain Management, Vol. 45 No. 4, pp. 38-54.

Rangan, V.K., Chu, M. and Petkoski, D. (2011), “The globe: segmenting the base of the pyramid”, Harvard Business Review, Vol. 89 No. 6, pp. 113-117.

Rivera-Santos, M. and Rufín, C. (2010), "Global village vs. small town: understanding networks at the base of the Pyramid”, International Business Review, Vol. 19 No. 2, pp. 126-139. 
Rodríguez, J.A., Giménez Thomsen, C., Arenas, D. and Pagell, M. (2016), "NGOs' initiatives to enhance social sustainability in the supply chain: poverty alleviation through supplier development programs", Journal of Supply Chain Management, Vol. 52 No. 3, pp. 83-108.

Sen, A. (1999), Commodities and Capabilities, Oxford University Press, Oxford.

Shenton, A.K. (2004), "Strategies for ensuring trustworthiness in qualitative research projects", Education for information, Vol. 22 No. 2, pp. 63-75.

Smith, A., Judge, W., Pezeshkan, A. and Nair, A. (2016), "Institutionalizing entrepreneurial expertise in subsistence economies", Journal of World Business, Vol. 51 No. 6, pp. 910-922.

Sodhi, M.S. and Tang, C.S. (2014), "Supply-chain research opportunities with the poor as suppliers or distributors in developing countries", Production and Operations Management, Vol. 23 No. 9, pp. 1483-1494.

Stephan, U., Uhlander, L. and Stride, C. (2015), "Institutions and social entrepreneurship: the role of institutional voids, institutional support, and institutional configurations", Journal of International Business Studies, Vol. 46 No. 3, pp. 308-331.

Tang, C.S. (2016), "Supply chain opportunities at the bottom of the pyramid", Decision, Vol. 43 No. 2, pp. 1-10.

Tate, W.L. and Bals, L. (2018), "Achieving shared triple bottom line (TBL) value creation: toward a social resource-based view (SRBV) of the firm", Journal of Business Ethics, Vol. 152 No. 3, pp. 803-826.

White, H. (2010), “A contribution to current debates in impact evaluation”, Evaluation, Vol. 16 No. 2, pp. 153-164.

Yin, R.K. (1994), Case Study Research - Design and Methods, Sage Publications, London.

\section{Corresponding author}

Eugenia Rosca can be contacted at: e.rosca@uvt.nl
Distribution models at the base of the pyramid

For instructions on how to order reprints of this article, please visit our website: 